\title{
Climatic Changes and Vulnerability of Household Food Accessibility: A Study on \\ Malaysian East Coast Economic Region
}

\author{
Md. Mahmudul Alam* \\ Senior Lecturer \\ School of Economics, Finance \& Banking \\ College of Business, Universiti Utara Malaysia \\ Kedah, Malaysia \\ E-mail: rony000@ gmail.com \\ Tel: +601-6279 9091 \\ Chamhuri Siwar \\ Emeritus Professor \\ Institute for Environment and Development (LESTARI) \\ National University of Malaysia (UKM) \\ 43600 UKM Bangi, Selangor Darul Ehsan, Malaysia \\ E-mail: csiwar@ukm.my \\ Basri Talib \\ Associate Professor \\ Faculty of Economics and Management \\ National University of Malaysia (UKM) \\ 43600 UKM Bangi, Selangor Darul Ehsan, Malaysia \\ E-mail: basri@ukm.my \\ Abu N.M. Wahid \\ Professor \\ Department of Economics and Finance \\ Tennessee State University \\ Nashville, Tennessee, USA \\ E-mail: awahid@tnstate.edu \\ Tel: +615-963-7149 \\ * Corresponding author
}

\section{Citation Reference:}

Alam, M.M., Siwar, C., Talib, B., and Wahid, A.N.M. 2017. Climatic Changes and Vulnerability of Household Food Accessibility in Malaysian East Coast Economic Region. International Journal of Climate Change Strategies and Management, 9(3): 387-401. http://www.emeraldinsight.com/doi/full/10.1108/IJCCSM-06-2016-0075

This is a pre-publication copy.

The published article is copyrighted by the publisher of the journal. 


\title{
Climatic Changes and Vulnerability of Household Food Accessibility: A Study on Malaysian East Coast Economic Region
}

\begin{abstract}
Purpose: Sustainable food security at the household level is one of the emerging issues for all nations. Several factors such as social, economic, political, demographic, natural, and livelihood strategies cause vulnerability in the status of household food security. This study is an attempt to examine the vulnerability of the factors of household food accessibility and its linkage with the climatic changes in Malaysia.
\end{abstract}

Design/methodology/approach: The study is based on primary data collected in the months of July - October, 2012 through a questionnaire survey on 460 low-income households from the East Coast Economic Region (ECER) in Malaysia. The samples were selected from $E$ Kasih poor household database, based on the cluster random sampling technique. The questionnaire uses a five-point Likert scale, and the data were analyzed using descriptive statistics and ANOVA F statistics for Chi-Square Two Sample Test.

Findings: The study finds that the vulnerability of the factors of household food accessibility has increased statistically and significantly over the last five years in Malaysia, whereas the contributions of climatic factors are low on these changes. This study suggests that the food security programs in Malaysia need to be integrated with the climatic change adaptation programs to ensure more effective and sustainable household food security in the future.

Originality/value: This study is an original work based on primary data that empirically measures the vulnerability of the factors of household food accessibility, one of the important dimensions of household food security, and its linkage with climatic changes.

Keywords: Climate Change; Household Food Security; Food Accessibility; Vulnerability; Poverty; Malaysia

Article Classification: Research paper

JEL Codes: I32, Q54, P48

\section{Introduction}

Food security is a critical global aspect of the individual and household wellbeing regardless of whether it is viewed locally, globally, or within communities. Hunger and food insecurity are detrimental to the basic rights of a human being and are a prelude to problems including health, nutrition, and development. The household food security is a more current understanding of the food security concept. Most of the literature in this subject from the 1980s assumes national food security to be similar to food self-sufficiency and this poses a few challenges. According to Debebe (1995), household food security represents factors, which are linked to the actions of "...acquisition, household procurement strategies, and socio-economic condition of the society."

Various types of indicators are required to measure the many different aspects of food security at an individual, household, and country levels (Hoddinott, 1999). Various correlated environmental, socioeconomic, and political aspects that need multi-pronged approaches have an influence on food security (Debebe, 1995). Negatu (2006) suggests that one of the factors that has an effect on food security is land tenure insecurity and the other is not having accessibility to productive resources, low educational level, reduction in land holdings, not having accessibility to proper transport structure, low livestock productivity, unaware of suitable interventions, bad storage technology, and a high unemployment level. Other factors that also have an effect on food security include crop pests, drought, and sudden torrential 
rainfall, not having a draught oxen, increased population, and shortage of land (Negatu, 2006).

Natural indicators result in specific higher variation in production costs and production that are linked to irrigation, infection and insecticide treatment, and higher losses (Lovendal \& Knowles, 2006). Depending on the capability of traders bringing in food from various other areas and the available stock levels, this could potentially disrupt food supply and cause prices to increase further. The main environmental indicators prove to be trends and not shocks that occur. They negatively affect production through reduced soil fertility and lower yields as well as the rise of production cost per unit. The profitability of farming and the potential to gain income from other resource based activities are limited.

There are four dimensions of food security such as availability of food, stability of its supply, accessibility to food, and utilization of food (FAO, 2005; 2008a). A vulnerable food system occurs when any dimensions of food security are insecure and uncertain. Understanding the vulnerability of the factors of food security can assist in the identification and comprehension of the fundamental dimension of a population's wellbeing, and to recognize the most vulnerable communities in the regions or subgroups.

Just like as other dimensions, household food accessibility is also very important for household food security, which indicates household access to sufficient and suitable food for a nutritious meal that households can gain access based on the legal, economic, political, and social arrangement of a community in which they live (including conventional rights such as access to normal resources). Garrett and Ruel (1999) point out that a household's accessibility to food is dependent on the income of the household to buy food at the current prices or if they have enough land and resources to produce the necessary food, besides receiving aid through prescribed programmes or other unofficial networks during times of need. Other factors besides the issues of price and income can also have an effect on the household's caloric availability. These include location, educational level of household members, and the demographic structure of the household (Garrett \& Ruel, 1999). Nyariki and Wiggins (1997) suggest that food access in a household is implicitly dependent on the capability to utilize physical, natural, and human resources efficiently. It includes the availability of resources such as labor and land, which has a significant role in the production of food and the ability to utilize these resources sufficiently, is the determinant of food security in the household.

According to Lovendal and Knowles (2006), food utilization and food accessibility are mainly affected at the household level by economic, social, health, and lifecycle related indicators. Being dependent on subsistence farming with no other income generating activities or no accessibility to markets can lower the availability of food among households. Life events such as weddings and funerals often incur a large amount of additional expense thus also lowering the capability for purchase of food. Likewise, disability, injuries, and illnesses incur extra expenses and lower the supply of labor and income, thus causing insufficient utilization of food. Economic indicators are able to lower food accessibility via the loss of income by being unemployed or due to the failure of income-generating activities such as farming, small manufacturing, or trade.

Malaysia is a fast growing developing country. Therefore, there are scopes of frequent changes in the macro variables that would affect food security. Moreover, climatic factors are changing rapidly in Malaysia and have been having adverse impacts on food production 
(Alam et al., 2010, 2011). As such, household food insecurity is not only related to social and economic factors, but is also statistically and significantly linked to the direct and indirect impacts of climatic factors (Alam et al., 2016a). Previous studies show that $50 \%$ or more of the low-income rural households face some level of food insecurity with $34.5 \%$ child hunger (Shariff \& Khor, 2008). The percentage of households with food insecurity in Malaysia is higher in urban low-income households, such as 66.6\% (Zalilah, 1998) and 65.7\% (Zalilah \& Ang, 2001) compared to rural low-income households at 58\% (Shariff \& Khor, 2008). Another recent study shows that among the poor and low-income households, $23.3 \%$ are mildly food insecure, $14.3 \%$ are moderately food insecure, and $9.6 \%$ are severely food insecure in Malaysia (Alam et al., 2016b).

Therefore, to understand the level of vulnerability of household food security, this study is an attempt to check food accessibility - one of the important dimensions of household food security, and its linkage to climatic changes in Malaysia.

\section{Climate Changes and Household Food Accessibility}

Climate changes affect the fundamental aspects of food production negatively, which include water, soil, and biodiversity. In a broader viewpoint, it has an effect on all the four types of food security's dimensions (FAO, 2008a). FAO also highlights the impacts of the components of climatic changes on household food accessibility that are given in Table 1.

Table 1: Impact of the Components of Climatic Changes on Household Food Accessibility

\begin{tabular}{|c|c|}
\hline Components of Climate Changes & Food Accessibility \\
\hline $\mathrm{CO} 2$ fertilization effects & $\begin{array}{l}\text { - Increases in food production would limit price } \\
\text { increases on world markets, but diversion of productive } \\
\text { assets to other cash crops could cause food prices to rise }\end{array}$ \\
\hline Increase in global mean temperatures & $\begin{array}{l}\text { - Impacts on incomes, prices, and affordability } \\
\text { uncertainty } \\
\text { - Changes in preference uncertainty }\end{array}$ \\
\hline $\begin{array}{l}\text { Gradual changes in precipitation (increase in the } \\
\text { frequency, duration and intensity of dry spells and } \\
\text { droughts) }\end{array}$ & $\begin{array}{l}\text { - Local increase in food prices in drought-affected areas } \\
\text { - Loss of farm income and non-farm employment } \\
\text { - Preferred foods not available or too costly }\end{array}$ \\
\hline $\begin{array}{l}\text { Gradual changes in precipitation (changes in } \\
\text { timing, location, and amounts of rain and } \\
\text { snowfall) }\end{array}$ & $\begin{array}{l}\text { - Full-cost pricing for water may cause food prices to } \\
\text { rise }\end{array}$ \\
\hline $\begin{array}{l}\text { Gradual changes in precipitation (increase in the } \\
\text { frequency, duration and intensity of dry spells and } \\
\text { droughts) }\end{array}$ & $\begin{array}{l}\text { - Local increase in food prices in drought-affected areas } \\
\text { - Loss of farm income and non-farm employment } \\
\text { - Preferred foods not available or too costly }\end{array}$ \\
\hline $\begin{array}{l}\text { Impacts of increase in the frequency and intensity } \\
\text { of extreme weather events (increase in annual } \\
\text { occurrence of high winds, heavy rains, storm } \\
\text { surges, flash floods and rising water levels } \\
\text { associated with tornados, tropical storms, and } \\
\text { prolonged heavy rains) }\end{array}$ & $\begin{array}{l}\text { - Possible increase in food prices } \\
\text { - Possible loss of farm income and non-farm } \\
\text { employment, depending on extent of asset loss }\end{array}$ \\
\hline Impacts of greater weather variability & $\begin{array}{l}\text { - Reduced yields may lead to loss of farm income, but } \\
\text { this depends on market conditions }\end{array}$ \\
\hline
\end{tabular}

Source: Compilation from Table 1: A, B, C.1, C.2, D, E (FAO, 2008a) 
In general, climate changes are expected to cause the number of people at risk from hunger to grow (FAO, 2005). In the case of rural people who tend to produce a large portion of food for own consumption, the effects of climate changes on food production may lower the availability to the extent that choices of allocation would have to be determined inside a household. Similar choices will be faced by the rural and urban non-farming low-income households whose incomes are below the poverty line due to the effects of climate changes. Urbanization is a worldwide phenomenon and a large number of the growing population in the urban areas that is considered poor (Ruel et al., 1998). Therefore, over time, the allocation problems due to climate changes would potentially become more prevalent in the urban areas compared to those of the rural.

Most food is not produced by individual households but received via borrowing, buying, and trading (Du Toit \& Ziervogel, 2004). Effects of climate changes on incomeearning activities can have an effect on buying food; and climate changes or extreme climates may impact the availability of certain food, which may affect the price. The high prices may cause some food to be unaffordable and can affect the nutrition and health of an individual.

The price of food may have an effect on households' food accessibility, by putting a constraint on the acquisition of suitable food for a balanced diet and the buying power of food aid schemes. Climate variations will probably cause a substantial rise in food prices (von Braun, 2007; Cline, 2007). Temperature rise of higher than $3^{\circ} \mathrm{C}$ may result in prices to go up by $40 \%$ (Easterling et al., 2007). For most countries, the ratio of the cost of daily minimum food basket to the daily income average is utilized as a method to calculate poverty (World Bank PovertyNet, 2008). If this ratio goes down lower than the fixed threshold, it shows that food is affordable and people can afford it; if it goes higher than the fixed threshold, it means that the food is not affordable and people face trouble trying to get sufficient food. This criterion indicates critical poverty and can be utilized to decide if people are experiencing temporary food insecurity, due to decreased food supply and higher prices, and/or due to a sudden dip in the household's income.

Plant and animal diseases and pests as well as invasive alien aquatic species related to climate changes will lower the quantity of food availability, affect the production system's stability and lower food accessibility by reducing the income gained from livestock, lower cash crops and food yields, reduce forest productivity and the aquatic populations, thus increasing the control costs (FAO, 2008b). The price of food will have an effect on food accessibility in households, by limiting the purchase of suitable food for a nutritious and balanced diet and to gain from food aid programmes.

The distance that food has to travel to get to the table of the consumer has an impact on its price (Pretty et al., 2006). Rise in fuel price could cause a higher cost of food, which in turn, can increase food insecurity. Biofuels are a growing market, which is anticipated to affect food security, because crops produced for feedstock as liquid biofuels can take the place of food crops, which have to be sourced from another place at a higher price.

Changes in demand for agricultural labor that is seasonal, due to changes in production caused by climate changes, can have an effect on income-generating ability either negatively or positively. The requirement for seasonal labor may decrease in many places due to mechanization and demands for labor are often lowered with crop failure, mostly due to flood, drought, pest outbreaks, or frost caused by climate changes. However, several adaptation choices may improve the demand for seasonal labor in agriculture. In most regions 
in the world, local food prices are strongly affected by conditions of the global market, but there may be short-term variations associated with changes in national yields, which are affected by climate changes, besides other factors. Food prices increase has a real effect on income, with low-income households often facing the most suffering, as they normally devote larger portions of their incomes to food compared to higher-income households (Thomsen \& Metz, 1998).

Food preferences ensure the types of food a household buys. Climate changes may have an effect on the economic and physical availability of some of the food preferred and this might the possibility of purchasing the preferred food. The changes in the price and availability of the main food variety may cause the households to change their normal food basket or use more of their total income to purchase some of the food when the prices have gone up. Food affordability is dependent on the association between the cost of a normal food basket and the household's income. Global food markets may show higher price volatility, disrupting the stability of profits for farmers and having access to purchased food for farming and non-farming poor households. Food emergencies, which increase the instability of supplies, due to climate changes, will probably increase the magnitude and frequency of food emergencies for which the global food system is not equipped to manage. Increased human conflicts, created partly due to migration and competition for limited resources also due to changing climatic conditions, could cause destabilization of food systems at all levels. Changes in climate will expand conflicts in many ways; however, these relationships must be addressed carefully. The higher frequencies of drought may cause communities to migrate to a new place, which can create conflict among people fighting for the same resources in the new place. Limited resources could also instigate conflicts and be the result of environmental changes globally.

\section{Data and Methodology}

\subsection{Data Collection}

Data for this study was collected through an extensive questionnaire survey at the household level in the East Coast Economic Region (ECER) in Malaysia. ECER is more than half of Peninsular Malaysia with the area of about $66,000 \mathrm{sq} \mathrm{km}$ that covers the states of Kelantan, Terengganu, Pahang, and Mersing in Johor. ECER is crucial for two major reasons: (a) ECER is the most vulnerable area in Malaysia due to climatic changes and (b) the income level of this region is low and poverty rate is high, which is an obstacle to achieve Vision 2020 (Alam et al., 2012).

This study is based on primary data collected from 460 households in the urban and rural areas of ECER. The urban area of Kuantan and rural area of Pekan were selected from the Pahang state. The urban area of Kota Bharu and the rural area of Tumpat were chosen from the Kelantan state. The urban area of Kuala Terengganu and the rural area of Maring were taken from the Terengganu state. A questionnaire guide technique was used to collect the data. The survey was conducted by the regular enumerators of the Implementation Coordination Unit (ICU) from Pahang, Kelantan, and Terengganu states in the months of July - October, 2012.

The survey follows the two-stage cluster random sampling technique. Initially the samples are clustered by location and then by poverty category. Finally, from each category, samples are picked randomly from the E-Kasih database. The E-Kasih system is an integrated 
database system that has enlisted poor households at the national level to plan, implement, and monitor poverty programs in Malaysia.

\subsection{Variables and Statistical Analysis}

There are many factors relevant to the vulnerability of household food accessibility due to climatic changes and non-climatic/general changes. To measure the degree of vulnerability of these factors and their linkage with climatic changes, the perceptions of the households have been shown in three forms - (a) measures the current level and five year's earlier level of these factors by using the five-point Likert scale of 1 (very low) to 5 (very high); (b) measures the changes in the factors by comparing the current level with a level of five years earlier; and (c) and measures the level of climatic influences on the changes of these factors over the five year period.

This study also examines the equality of two means between the current status of the relevant factors and five years earlier factors through the ANOVA F statistics for Chi-Square $\left(\chi^{2}\right)$ Two Sample Test.

$$
\chi^{2}=\sum_{i=1}^{n} \frac{\left(O_{i}-E_{i}\right)^{2}}{E_{i}}
$$

Here, $\mathrm{O}_{\mathrm{i}}=$ Current Status of $i$ - th Factors (Ordinal Data)

$\mathrm{E}_{\mathrm{i}}=$ Five years earlier Status of $i$ - th Factors (Ordinal Data)

The variables that are considered in this study are as follows:

X1 Prices of general food items

X2 Difference between rural and city food prices

X3 Price differences among shops in the local market

X4 Household food shortage caused by high food prices

X5 Stability of food price in market

X6 Level of household income

X7 Household food shortage caused by low level of income

X8 Household budget arrangements to buy food anytime

X9 Household access of quick credit to buy food

X10 Availability of discount or offer on food price in the local market

X11 Efficiency of household food acquisition or collection system

X12 Household dependencies on common resources for cattle or livestock feeding

X13 Competition among people for common resources

X14 Food and medicine expenditure for cattle and livestock

X15 Household food security related supports from agencies

\section{Analysis and Discussions}

\subsection{Demographic Characteristics}

Among the respondents of the study, around $60 \%$ are selected from the urban area and $40 \%$ from the rural area. In total, $69.8 \%$ are male and $30.2 \%$ are female respondents. The male respondents are $69.7 \%$ among the urban respondents and $69.8 \%$ among the rural respondents. Males are the majority group, and the respondents represent the household data. 
The average age of all respondents is 50.7 years whereby male is 48.9 and female is 54.7 years old. Among the male respondents, the maximum age is 83 and minimum age is 26 years old. Among the female respondents, the maximum age is 83 and minimum age is 25 years old. In total, only $3.7 \%$ are below 30 years old, and $23 \%$ are above 60 years old. The maximum number of respondents is in the age range of 30-40 years at $35.2 \%$ of the total. Exception is only for the rural area of Kelantan where maximum number of participants is in the age group of 50-60 years old.

Most of the respondents have secondary education (46.5\%) followed by basic primary education (35.9\%). Only 3\% of the respondents have certificate/diploma level education and $14.6 \%$ are illiterate. Numbers of illiterate people are higher in the urban area at $17.3 \%$ whereas in the rural area, it is at $12.7 \%$.

Among the total respondents, $72.8 \%$ are married whereas $3 \%$ are unmarried. Total of $24.2 \%$ of the respondents are found to be widowed or divorced. Most of the families $(20.7 \%)$ have 5 persons in the household and average family members is 5.6 persons per household. There are 1-3 persons available in $17.9 \%$ of the households. There are 8 or more people available in $17.9 \%$ of the households.

Among the respondents, most of the households (63.3\%) have no children (below 6 years) and average number of children (below 6 years) per household is 0.6 . Majority of them have only one child and their ratio is $20.9 \%$. Most of the households $(24.1 \%)$ have no school going children (below 6 years) and the average number of school going children per household is 2.2. Families that have 2-3 school going children are $40.3 \%$.

Among the households, $83.7 \%$ have their own residence. This proportion is same for both urban and rural households. In the rural area, $50.9 \%$ of houses are made up of mixed types (using both brick and wood) of houses. In the urban area, 34.6\% of people live both in mixed and wood made houses.

The respondents are engaged in various types of jobs, such as babysitter, batik designer, building contractor, small business, bus driver, canteen assistant, car service, carpenter, chef , clerk, cleaner, construction worker, craftsman, electrical technician, van driver, fisherman, fruit dealer, furniture shopkeeper, gardener, jewelry shopkeeper, hawker, daily labor, farmer, mason, painter, plumber, saloon worker, security guard, imam, teacher, government servant, tailor, taxi driver, welding worker, factory laborer, etc. In $90 \%$ of the cases, the heads of the households do not have any supplementary job. The rural households have more supplementary job options than urban households. The spouses of most of the households (88.3\%) are not engaged in any job. However, the number of spouses of urban households engaged in jobs is more compared to those of the rural households.

Around $76.3 \%$ of the households have only one earning member; $15.7 \%$ have two earning members, and $5.4 \%$ have three earning members. The proportion is almost the same for the urban and rural areas. At the household level, on an average, the earning family members to total family members' ratio is 0.287 , indicating that on an average, only $28.7 \%$ of the family members are engaged in economic activities. Among the surveyed households, in $47.2 \%$ of the cases, this ratio is up to 0.2 , and in $3.7 \%$ of the cases, the ratio is 1 which means a single person family. 
The household income of most of the respondents is between RM 5,001-1,000 range. $35 \%$ of the household's monthly income is up to RM500, which is more in the urban area in comparison to that of the rural area. Only $3.6 \%$ of a household's income is above RM 2,000, which is more in the rural area in comparison to the urban area. The per-capita income of most of the respondents is between RM 100-200. The per-capita income of $59.3 \%$ of respondents is up to RM 200.

According to the survey findings, around 55\% are still poor and hard core poor. Around $9 \%$ of the people have an income of more than RM 400. The people in the low household income group also belong to the low per-capita income group. ${ }^{1}$

The distribution of income among the surveyed household is not that wide. However, here, the top $10 \%$ earn $23.2 \%$ of the total income while the bottom $10 \%$ earn only $3.4 \%$ of the income, and the top $20 \%$ earn $36.9 \%$ of the total income while the bottom $20 \%$ earn only $8.8 \%$.

The degree of inequality is measured by the Inequality Ratio, also known as the Kuznets' ratio. The ratio measures inequality through the ratio of income of top $20 \%$ to that of the bottom $40 \%$. Here, the ratio is $1.624((1-0.631) / 0.227)$, meaning that the degree of inequality at household level is more than one and a half times. Moreover, if the inequality ratio is measured in terms of population instead of household, the degree of inequality is roughly $1.405(0.358 / 0.255)$. The degree of inequality at the population level is less than the household level because there are likely less population in the poorer households and more population in the richer households.

The most vulnerable groups are those who have no household saving and as a result, their per capita savings is nil. Among the respondents, around $82 \%$ do not have any savings. Therefore, any type of spike in regular life due to natural disasters, disease, crime, or social issues will push them towards borrowing. The rural households save less compared to the urban households.

\subsection{Assessment of Vulnerability}

The changes in the prices of general food items (X1) in Malaysia over the last five years are found statistically significant at $1 \%$ level (Table 3). Around $81.5 \%$ of the respondents mention the changes are positive and overall, the average score increases from 2.5 to 3.9 (Table 2). It indicates that the vulnerability of the prices of general food items in Malaysia has increased over the time.

Table 2: Status of the factors of food accessibility over the five years period

\begin{tabular}{|c|c|c|c|c|c|c|c|c|c|c|}
\hline \multirow{2}{*}{ Issues } & \multirow{2}{*}{$\begin{array}{c}\text { Time } \\
\text { Frame }\end{array}$} & \multicolumn{5}{|c|}{ Observation Scale* } & \multirow{2}{*}{$\begin{array}{l}\text { Average } \\
\text { value of } \\
\text { the score } \\
\end{array}$} & \multirow{2}{*}{ S.D. } & \multirow{2}{*}{\multicolumn{2}{|c|}{$\begin{array}{cc}\text { Proportion of } & \text { Proportion of } \\
\text { High (4 \& 5) } & \text { Low (1 \& 2) } \\
\text { Observation } & \text { Observation } \\
\end{array}$}} \\
\hline & & 1 & 2 & 3 & 4 & 5 & & & & \\
\hline $\mathrm{X} 1$ & curren & 4 & 13 & 13 & 26 & 104 & 3.90 & $\overline{0.81}$ & $71.7 \%$ & $3.7 \%$ \\
\hline
\end{tabular}

\footnotetext{
${ }^{1}$ The hardcore poor are considered those with Ringgit Malaysia (RM) 0-110 income per person per month for the rural area, and RM 0-120 RM per person per month for the urban area. The poor are considered those with RM 111-185 income per person per month, for the rural area and RM 121-200 per person per month, for the urban area. The recently and previously marginally non-poor (mudah miskin and terkeluar) make more than RM 185 , per person per month, for the rural area and RM 200, per person per month, for the urban area.
} 


\begin{tabular}{|c|c|c|c|c|c|c|c|c|c|c|}
\hline & 5 years ago & 29 & 175 & 243 & 13 & 0 & 2.52 & 0.66 & $2.8 \%$ & $44.3 \%$ \\
\hline \multirow{2}{*}{$\mathrm{X} 2$} & Current & 25 & 28 & 159 & 193 & 55 & 3.49 & 0.97 & $53.9 \%$ & $11.5 \%$ \\
\hline & 5 years ago & 38 & 118 & 229 & 73 & 2 & 2.75 & 0.84 & $16.3 \%$ & $33.9 \%$ \\
\hline \multirow[t]{2}{*}{ X3 } & Current & 18 & 43 & 211 & 162 & 26 & 3.29 & 0.86 & $40.9 \%$ & $13.3 \%$ \\
\hline & 5 years ago & 24 & 84 & 295 & 53 & 4 & 2.85 & 0.72 & $12.4 \%$ & $23.5 \%$ \\
\hline \multirow[t]{2}{*}{$\mathrm{X} 4$} & Current & 70 & 49 & 155 & 169 & 17 & 3.03 & 1.11 & $40.4 \%$ & $25.9 \%$ \\
\hline & 5 years ago & 90 & 116 & 195 & 53 & 6 & 2.50 & 0.98 & $12.8 \%$ & $44.8 \%$ \\
\hline \multirow[t]{2}{*}{$\mathrm{X} 5$} & Current & 10 & 35 & 106 & 246 & 63 & 3.69 & 0.88 & $67.2 \%$ & $9.8 \%$ \\
\hline & 5 years ago & 30 & 157 & 250 & 23 & 0 & 2.58 & 0.69 & $5.0 \%$ & $40.7 \%$ \\
\hline \multirow[t]{2}{*}{ X6 } & Current & 44 & 131 & 242 & 39 & 4 & 2.63 & 0.81 & $9.3 \%$ & $38.0 \%$ \\
\hline & 5 years ago & 48 & 222 & 175 & 15 & 0 & 2.34 & 0.71 & $3.3 \%$ & $58.7 \%$ \\
\hline \multirow[t]{2}{*}{$\mathrm{X} 7$} & Current & 112 & 71 & 195 & 70 & 12 & 2.56 & 1.09 & $17.8 \%$ & $39.8 \%$ \\
\hline & 5 years ago & 122 & 117 & 185 & 28 & 8 & 2.31 & 0.99 & $7.8 \%$ & $52.0 \%$ \\
\hline \multirow{2}{*}{ X8 } & Current & 80 & 92 & 202 & 71 & 15 & 2.67 & 1.04 & $18.7 \%$ & $37.4 \%$ \\
\hline & 5 years ago & 106 & 120 & 200 & 24 & 10 & 2.37 & 0.97 & $7.4 \%$ & $49.1 \%$ \\
\hline \multirow[t]{2}{*}{ X9 } & Current & 168 & 62 & 158 & 60 & 12 & 2.32 & 1.17 & $15.7 \%$ & $50.0 \%$ \\
\hline & 5 years ago & 164 & 115 & 139 & 41 & 1 & 2.13 & 1.01 & $9.1 \%$ & $60.7 \%$ \\
\hline \multirow[t]{2}{*}{$\mathrm{X} 10$} & Current & 37 & 48 & 252 & 99 & 24 & 3.05 & 0.92 & $26.7 \%$ & $18.5 \%$ \\
\hline & 5 years ago & 86 & 121 & 215 & 35 & 3 & 2.45 & 0.90 & $8.3 \%$ & $45.0 \%$ \\
\hline \multirow[t]{2}{*}{ X11 } & Current & 116 & 28 & 221 & 85 & 10 & 2.66 & 1.11 & $20.7 \%$ & $31.3 \%$ \\
\hline & 5 years ago & 116 & 104 & 220 & 19 & 1 & 2.32 & 0.90 & $4.3 \%$ & $47.8 \%$ \\
\hline \multirow[t]{2}{*}{$\mathrm{X} 12$} & Current & 246 & 38 & 68 & 78 & 30 & 2.15 & 1.39 & $23.5 \%$ & $61.7 \%$ \\
\hline & 5 years ago & 230 & 43 & 133 & 51 & 3 & 2.03 & 1.14 & $11.7 \%$ & $59.3 \%$ \\
\hline \multirow[t]{2}{*}{ X13 } & Current & 164 & 65 & 122 & 65 & 43 & 2.49 & 1.38 & $23.5 \%$ & $49.8 \%$ \\
\hline & 5 years ago & 214 & 45 & 127 & 70 & 4 & 2.14 & 1.19 & $16.1 \%$ & $56.3 \%$ \\
\hline \multirow[t]{2}{*}{ X14 } & Current & 245 & 26 & 103 & 57 & 29 & 2.13 & 1.34 & $18.7 \%$ & $58.9 \%$ \\
\hline & 5 years ago & 253 & 66 & 91 & 50 & 0 & 1.87 & 1.08 & $10.9 \%$ & $69.3 \%$ \\
\hline \multirow[t]{2}{*}{$\mathrm{X} 15$} & Current & 110 & 42 & 149 & 103 & 56 & 2.90 & 1.32 & $34.6 \%$ & $33.0 \%$ \\
\hline & 5 years ago & 128 & 124 & 150 & 52 & 6 & 2.31 & 1.04 & $12.6 \%$ & $54.8 \%$ \\
\hline
\end{tabular}

*Scale: 1= Very Low, 2= Low, 3= Normal, 4= High, 5= Very High

Table 3: Statistical significance of the changes in the factors of food accessibility over the

\begin{tabular}{lrrrr}
\hline \multirow{2}{*}{ Issues } & \multicolumn{3}{c}{ five years period } \\
\cline { 2 - 4 } Xerception of Changes & $\begin{array}{c}\text { Chi-Square } \\
\text { Value }\end{array}$ \\
\hline \hline X1 & Decrease & \multicolumn{1}{c}{ Same } & \multicolumn{1}{c}{ Increase } & $46.8^{*}$ \\
X2 & $9(2 \%)$ & $76(16.5 \%)$ & $375(81.5 \%)$ & $283.9^{*}$ \\
X3 & $39(8.5 \%)$ & $154(33.5 \%)$ & $267(58 \%)$ & $403.4^{*}$ \\
X4 & $32(7 \%)$ & $240(52.2 \%)$ & $188(40.9 \%)$ & $453.8^{*}$ \\
X5 & $33(7.2 \%)$ & $212(46.1 \%)$ & $215(46.7 \%)$ & $41.4^{*}$ \\
X6 & $34(7.4 \%)$ & $67(14.6 \%)$ & $359(78 \%)$ & $331.8^{*}$ \\
X7 & $38(8.3 \%)$ & $268(58.3 \%)$ & $154(33.5 \%)$ & $518.2^{*}$ \\
X8 & $49(10.7 \%)$ & $257(55.9 \%)$ & $154(33.5 \%)$ & $662.9^{*}$ \\
X9 & $26(5.7 \%)$ & $290(63 \%)$ & $144(31.3 \%)$ & $582.8^{*}$ \\
X10 & $36(7.8 \%)$ & $300(65.2 \%)$ & $124(27 \%)$ & $249.4^{*}$ \\
X11 & $30(6.5 \%)$ & $237(51.5 \%)$ & $193(42 \%)$ & $533^{*}$ \\
X12 & $19(4.1 \%)$ & $288(62.6 \%)$ & $153(33.3 \%)$ & $770.5^{*}$ \\
X13 & $33(7.2 \%)$ & $311(67.6 \%)$ & $116(25.2 \%)$ & $517.9^{*}$
\end{tabular}




\begin{tabular}{rrrrr} 
X14 & $20(4.3 \%)$ & $324(70.4 \%)$ & $116(25.2 \%)$ & $622.2^{*}$ \\
$\mathrm{X} 15$ & $37(8 \%)$ & $258(56.1 \%)$ & $165(35.9 \%)$ & $528.4^{*}$ \\
\hline
\end{tabular}

* Significant at $1 \%$ level

The changes in the difference between the rural and city food prices (X2) in Malaysia over the last five years are found statistically significant at 1\% level (Table 3). Around 58\% of the respondents mention that changes are positive and overall the average score increases from 2.75 to 3.49 (Table 2). It indicates that the vulnerability of the prices of general food items in Malaysia has increased over the time.

The changes in the price differences among shops in the local market (X3) over the last five years are found to be statistically significant at $1 \%$ level (Table 3). However, only $40.9 \%$ of the respondents mention the changes are positive and overall, the average score increases from 2.85 to 3.29 (Table 2). It indicates that the vulnerability of the price differences among shops in the local market has increased over time.

The changes in the household food shortage caused by high food prices (X4) in Malaysia over the last five years are found to be statistically significant at $1 \%$ level (Table 3). However, only $46.7 \%$ of the respondents mention the changes are positive and overall, the average score increases from 2.5 to 3.03 (Table 2). It indicates that the vulnerability of the household food shortage caused by high food prices in Malaysia has increased over time.

The changes in the stability of food price in the market (X5) over the last five years are found to be statistically significant at $1 \%$ level (Table 3). Around $78 \%$ of the respondents mention the changes are positive and overall, the average score increases from 2.58 to 3.69 (Table 2). It indicates that the vulnerability of the stability of food price in market has decreased over time.

The changes in the level of household income (X6) in Malaysia over the last five years are found to be statistically significant at $1 \%$ level (Table 3 ). However, only $33.5 \%$ of the respondents mention the changes are positive and overall, the average score increases from 2.63 to 2.34 (Table 2). It indicates that the vulnerability of the level of household income in Malaysia has increased over time.

The changes in the household food shortage caused by low level of income (X7) in Malaysia over the last five years are found to be statistically significant at $1 \%$ level (Table 3). However, only $33.5 \%$ of the respondents mention the changes are positive and overall, the average score increases from 2.56 to 2.31 (Table 2). It indicates that the vulnerability of the household food shortage caused by a low level of income in Malaysia has increased over time.

The changes in the household budget arrangement, ready to buy food anytime (X8) in Malaysia over the last five years are found to be statistically significant at $1 \%$ level (Table 3). However, only $31.3 \%$ of the respondents mention that the changes are positive and overall, the average score increases from 2.67 to 2.37 (Table 2). It indicates that the vulnerability of the household budget arrangement, ready to buy food anytime in Malaysia has decreased over time.

The changes in the household access of quick credit to buy food (X9) over the last five years are found to be statistically significant at 1\% level (Table 3). However, only 27\% 
of the respondents mention that the changes are positive and overall, the average score increases from 2.13 to 2.32 (Table 2). It indicates that the vulnerability of the household access to quick credit to buy food has decreased over time.

The changes in the availability of discount offer on food price in the local market (X10) in Malaysia over the last five years are found to be statistically significant at $1 \%$ level (Table 3). However, only $42 \%$ of the respondents mention that the changes are positive and overall, the average score increases from 3.05 to 2.45 (Table 2). It indicates that the vulnerability of the availability of discount offer on food price in the local market in Malaysia has decreased over time.

The changes in the efficiency of household food acquisition or collection system (X11) in Malaysia over the last five years are found to be statistically significant at $1 \%$ level (Table 3). However, only $33.3 \%$ of the respondents mention that the changes are positive and overall, the average score increases from 2.66 to 2.32 (Table 2). It indicates that the vulnerability of the efficiency of household food acquisition or collection system has decreased over time.

The changes in the household dependency on common resources for cattle or livestock feeding (X12) in Malaysia over the last five years are found to be statistically significant at $1 \%$ level (Table 3). However, only $25.2 \%$ of the respondents mention that the changes are positive and overall the average score increases from 2.15 to 2.03 (Table 2). It indicates that the vulnerability of the household dependency on common resources for cattle or livestock feeding in Malaysia has increased over time.

The changes in the competition among people for common resources (X13) in Malaysia over the last five years are found to be statistically significant at $1 \%$ level (Table 3). However, only $31.7 \%$ of the respondents mention the changes are positive and overall, the average score increases from 2.49 to 2.14 (Table 2). It indicates that the vulnerability of the competition among people for common resources in Malaysia has increased over time.

The changes in the food and medicine expenditures for cattle and livestock (X14) in Malaysia over the last five years are found to be statistically significant at $1 \%$ level (Table 3). However, only $25.2 \%$ of the respondents mention that the changes are positive and overall, the average score increases from 2.13 to 1.87 (Table 2). It indicates that the vulnerability of the food and medicine expenditures for cattle and livestock in Malaysia has increased over time.

The changes in the household food security related supports from agencies (X15) over the last five years are found to be statistically significant at $1 \%$ level (Table 3). However, only $35.9 \%$ of the respondents mention that the changes are positive and overall, the average score increases from 2.31 to 2.9 (Table 2). It indicates that the vulnerability of the price household food security related supports from agencies has decreased over time.

Table 4: Climatic influences on the changes in factors of food accessibility over a five-year

\begin{tabular}{|c|c|c|c|c|c|c|c|c|c|}
\hline \multicolumn{10}{|c|}{ period } \\
\hline \multirow{2}{*}{ Issues } & \multicolumn{5}{|c|}{ Observation Scale* } & \multirow{2}{*}{$\begin{array}{l}\text { Average } \\
\text { value of } \\
\text { the score } \\
\end{array}$} & \multirow{2}{*}{ S.D. } & \multirow{2}{*}{$\begin{array}{l}\text { Proportion of } \\
\text { High }(4 \& 5) \\
\text { Observation } \\
\end{array}$} & \multirow{2}{*}{$\begin{array}{l}\text { Proportion of } \\
\text { Low }(1 \& \text { \& }) \\
\text { Observation } \\
\end{array}$} \\
\hline & 1 & 2 & 3 & 4 & 5 & & & & \\
\hline$\overline{\mathrm{X} 1}$ & 289 & 40 & 57 & 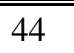 & 30 & 1.88 & 1.31 & $16.1 \%$ & $71.5 \%$ \\
\hline X2 & 327 & 51 & 53 & 26 & 3 & 1.54 & 0.95 & $6.3 \%$ & $82.2 \%$ \\
\hline
\end{tabular}




\begin{tabular}{lrrrrrrrrr} 
X3 & 358 & 29 & 58 & 15 & 0 & 1.41 & 0.83 & $3.3 \%$ & $84.1 \%$ \\
X4 & 283 & 40 & 53 & 69 & 15 & 1.90 & 1.27 & $18.3 \%$ & $70.2 \%$ \\
X5 & 285 & 51 & 73 & 39 & 12 & 1.76 & 1.14 & $11.1 \%$ & $73.0 \%$ \\
X6 & 330 & 35 & 70 & 18 & 7 & 1.56 & 0.99 & $5.4 \%$ & $79.3 \%$ \\
X7 & 343 & 50 & 53 & 13 & 1 & 1.43 & 0.82 & $3.0 \%$ & $85.4 \%$ \\
X8 & 373 & 25 & 54 & 7 & 1 & 1.34 & 0.76 & $1.7 \%$ & $86.5 \%$ \\
X9 & 397 & 16 & 39 & 7 & 1 & 1.26 & 0.69 & $1.7 \%$ & $89.8 \%$ \\
X10 & 326 & 34 & 88 & 12 & 0 & 1.53 & 0.89 & $2.6 \%$ & $78.3 \%$ \\
X11 & 361 & 27 & 66 & 5 & 1 & 1.39 & 0.79 & $1.3 \%$ & $84.3 \%$ \\
X12 & 380 & 17 & 45 & 17 & 1 & 1.35 & 0.82 & $3.9 \%$ & $86.3 \%$ \\
X13 & 369 & 38 & 44 & 9 & 0 & 1.33 & 0.73 & $2.0 \%$ & $88.5 \%$ \\
X14 & 383 & 23 & 48 & 6 & 0 & 1.30 & 0.71 & $1.3 \%$ & $88.3 \%$ \\
X15 & 352 & 22 & 59 & 26 & 1 & 1.48 & 0.93 & $5.9 \%$ & $81.3 \%$ \\
\hline *Scale: 1= Very Low, 2= Low, 3= Normal, 4= High, 5= Very High
\end{tabular}

For all of the cases, most of the respondents mention that the influences of climatic factors are low for the changes of these factors of household food accessibility over the five years (Table 4).

\section{Conclusions}

The study finds that the vulnerability of the factors of household food accessibility has changed statistically and significantly over the last five years. The mean values of the current status of these factors of household food security differ significantly at $1 \%$ significance level from the scenario of 5 years ago. The vulnerability of the household food accessibility increases due to the increases in the prices of general food items, food prices inequity between rural and urban locality, price differences among shops in the local market, high prices leading to food shortage, changes in the household income, income led food shortage, dependency on common resources for cattle or livestock feeding, competition among people for common resources, and food and medicine expenditures for cattle and livestock. However, vulnerability of the household food accessibility decreases due to the increases in the stability of food price in market, household budget arrangement to buy food anytime, household access of quick credit to buy food, discount offer on food price in the local market, efficiency of the household food acquisition or collection system, and the household food security related supports from agencies. However, in most of the cases, climatic issues have been found less responsible in the changes of these factors.

\section{Recommendations}

There should be some initiatives taken by the government in response to these factors that increase the vulnerability of the household food accessibility. There should be a proper monitoring body to ensure a consistent supply of food at regular prices both in the rural and urban markets, especially during times of natural calamity or off-season fluctuations. At the same time, income augmenting activities also need to be emphasized. The dependency on common resources is high for poor and low-income groups. Therefore, initiative for common resource protection and awareness creations are also important for the sustainable management of the common resources.

Although Malaysia is adversely affected by climatic changes, the factors of the household food accessibility have not yet been remarkably affected. However, climate changes are considered one of the major potential threats for household food security in 
Malaysia. Therefore, to ensure a sustainable household food security in Malaysia, the design of food security programs must integrate climatic changes into the picture, and food security approaches must recognize climate changes as an important driver. This integration would also increase household capacity to adapt to climatic changes. At the same time, it must be ensured that the climate changes adaptation approaches and strategies that reduce vulnerability to climate changes also increase the household food security.

\section{Acknowledgement}

We are thankful to the Ministry of Science, Technology and Environment of the Government of Malaysia for generously funding the research, under the Research University Grant Project UKM-GUP-PI-08-34-081, AP-2014-017, and FRGS/1/2012/SS07/UKM/01/3.

\section{References}

Alam, M.M., Siwar, C., \& Al-Amin, A.Q. 2010. Climate Change Adaptation Policy Guidelines for Agricultural Sector in Malaysia, Asian Journal of Environmental and Disaster Management 2(4): 463-469.

Alam, M.M., Siwar, C., Talib, B., \& Mohd Ekhwan, T. 2011. The Relationships between the Socioeconomic Profile of Farmers and Paddy Productivity in North-West Selangor, Malaysia, Asia-Pacific Development Journal 18(1): 161-173.

Alam, M.M., Morshed, G., Siwar, C. \& Murad, M.W. 2012. Initiatives and Challenges of Agricultural Crop Sector in ECER Development Projects in Malaysia, AmericanEurasian Journal of Agricultural \& Environmental Science 12(7): 922-931.

Alam, M.M., Talib, B., Siwar, C., \& Wahid, A.N.M. 2016a. Climate Change and Food Security of the Malayan East Coast Poor: A Path Modeling Approach. Journal of Economic Studies 43(3): 1-17.

Alam, M.M., Siwar, C., Wahid, A.N.M., \& Talib, B. 2016b. Food Security and Low-Income Households in the Malaysian East Coast Economic Region: An Empirical Analysis. Review of Urban \& Regional Development Studies 28(1): 2-15.

Cline, W.R. 2007. Global warming and agriculture: Impact estimates by country. Washington, DC: Center for Global Development and Peterson Institute for international Economics.

Debebe, H. 1995. Food security: A brief review of concepts and indicators. In Multa, D., Wolday, A., Simeon, E. \& Tesfaye, Z. (ed.). Food security, nutrition and poverty alleviation in Ethiopia problems and prospects, pp.1-18. Addis Ababa: Agricultural Economics society of Ethiopia.

Du Toit, A. \& Ziervogel, G. 2004. Vulnerability and food insecurity: Background concepts for informing the development of a national FIVIMS for South Africa (online). www.agis.agric.za/agisweb/FIVIMS_ZA (Accessed on 15 December 2016).

Easterling, W.E., Aggarwal, P.K., Batima, P., Brander, K.M., Erda, L., Howden, S.M., Kirilenko, A., Morton, J., Soussana, J-K., Schmidhuber, J. \& Tubiello , F.N. 2007. Food, Fibre and Forest Products. In Parry, M.L., Canziani, O.F., Palutikof, J.P., van der Linden, P.J. \& Hanson, C.E. (ed.). Climate change 2007: Impacts, adaptation and vulnerability. Contribution of working group II to the fourth assessment report of the intergovernmental panel on climate change, pp. 273-314. Cambridge: Cambridge University Press.

FAO. 2005. The State of Food Insecurity in the World 2005. Rome: Food and Agriculture Organization of the United Nations. 
FAO. 2008a. Climate Change and Food Security: A Framework Document. FAO interdepartmental working group on climate change. Rome: Food and Agriculture Organization of the United Nations.

FAO. 2008b. Expert Meeting on Climate-Related Transboundary Pests and Diseases Including Relevant Aquatic Species, Food and Agriculture Organization of the United Nations. Rome: Food and Agriculture Organization of the United Nations.

Garrett, J.L. \& Ruel, M.T. 1999. Are determinants of rural and urban food security and nutritional status different? Some insight from Mozambique. World Development 27(11): 1959-1975.

Hoddinott, J. 1999. Choosing outcome indicators of household food security. Washington DC: IFPRI.

Lovendal, C.R. \& Knowles, M. 2006. Tomorrow's hunger: A framework for analysing vulnerability to food security, UNU-WIDER. Research Paper No, 2006/119.

Negatu, W. 2006. Determinants of small farm household food security: evidence from south Wollo, Ethiopia. Ethiopian Journal of Development Research 28(1): 1-29.

Nyariki, D.M. \& Wiggins, S. 1997. Household food insecurity in Sub-Saharan Africa: Lesson from Kenya. British Food Journal 99(7): 249-262.

Pretty, J.N., Nobel, A.D., Bossio, D., Dixon, J., Hine, R.E., Penning de Vries, F.W.T. \& Morison, J.I.L. 2006. Resource-conserving agriculture increases yields in developing countries. Environmental Science and Technology 40(4): 1114-1119.

Ruel, M.T., Garrett, J., Morris, S., Maxwell, D., Oshaug, A., Engele, P., Menon, P., Slack, A. \& Haddad, L. 1998. Urban challenges to food and nutrition security: A review of food security, health and caregiving in the cities. Washington DC: IFPRI.

Shariff, Z.M. \& Khor, G.L. 2008. Household food insecurity and coping strategies in a poor rural community in Malaysia. Nutrition Research and Practice 2(1): 26-34.

Thomsen, A. \& Metz, M. 1998. Implications of economic policy for food security: A training manual. Rome: FAO and the German Agency for Technical Cooperation (GTZ).

Von Braun, J. 2007. The world food situation: new driving forces and required actions. Washington DC: International Food Policy Research Institute.

World Bank PovertyNet. 2008. Measuring poverty (online). http://go.worldbank.org/VCBLGGE250 (Accessed on 15 December 2016).

Zalilah, M.S. \& Ang, M. 2001. Assessment of food insecurity among low income households in Kuala Lumpur using the Radimer/ Cornell food insecurity instrument - A validation study. Malaysian Journal of Nutrition 7: 15-32.

Zalilah, M.S. 1998. Growth status determinants of school age children from primarily lowincome households in the urban area of Kuala Lumpur, Malaysia: A focus on intrahousehold factors. PH.D Dissertation, Michigan State University of USA. 
Biographical notes: Md. Mahmudul Alam is a Senior Lecturer of Finance at Universiti Utara Malaysia (UUM). He is also affiliated with Accounting Research Institutes (ARI) at University Technology MARA (UiTM) in Malaysia and International Islamic University Chittagong (IIUC) in Bangladesh as a Research Associate. He obtained Ph.D. and Master's degrees in Environment and Development (Fin. \& Econ.) from National University of Malaysia (UKM) and Bachelor (Hons) degree in Business Administration (Fin. \& Econ.) from North South University (NSU) in Bangladesh. He has a good number of publications including 95+ articles in refereed journals and five books/ monographs. He has presented articles in 60+ international conferences. He is recognized as one of the "Top Bangladesh Development Researchers of the Millennium" by BDRC. His research areas include sustainable development, ecological economics, Islamic economics, governance, finance \& investment, etc.

Chamhuri Siwar is an Emeritus Professor and Principal Research Fellow at the Institute for Environment and Development (LESTARI), National University of Malaysia (UKM). He has been serving UKM as a lecturer, head of department, and research fellow for more than 40 years. He graduated from UKM, Leeds and Iowa State University in the areas of Applied Economics, Agriculture and Resource Economics. He has successfully supervised 40 Ph.D. and 20 Master's students. He has been external examiners of numerous graduate students in Malaysia and abroad. He has wide publications in reputed international and national journals. His area of specialization includes Agricultural and Resource Economics, Rural Economics, Environmental Economics, Poverty and Income Distribution, Sustainable Economics, Socioeconomics Impact, and Sustainable Livelihood Studies.

Basri Abdul Talib is an Associate Professor of Economics at National University of Malaysia (UKM). He obtained his PhD in Agricultural Economics from Aberdeen University in 1998. His major areas of research are related to the environmental and natural resources economics, and rural development.

Abu N. M. Wahid is a Professor of Economics at Tennessee State University and the Managing Editor of the Journal of Developing Areas. Up until now, he has produced SIX books as author, editor, and co-editor and has made about 60 publications in the form of refereed journal articles and book chapters. Professor Wahid received many research grants including the Fulbright Research Fellowship in 1997. He is the recipient of the faculty excellence awards for research at Tennessee State University and Eastern Illinois University. Professor Wahid has visited academic institutions in about 20 different countries to give public lectures and seminar presentations. Since 2008, he delivered 4 Keynote addresses in international conferences held in Malaysia, the Philippines, and Taiwan. He read and reviewed $20 \mathrm{Ph} . \mathrm{D}$. dissertations as external examiner for various reputed universities around the world. 